614 ウェーブレット変換を用いた二自由度 Duffing 系の

\title{
確率論的ジャンプ現象の解析
}

\section{Analysis for stochastic jump phenomena of 2-DOF Duffing oscillator using wavelet transform}

\author{
○学 前川瞬 (島根大・院) 正 田村晋司 (島根大)
}

Jun MAEKAWA, Shimane University, 1060 Nishikawatsu-cho, Matsue-shi, Shimane

Shinji TAMURA, Shimane University

Key Words : Duffing Oscillator, Random Vibration, Wavelet Transform, 2-DOF system, Narrow Band

Excitation, Stochastic Jump Phenomena

\section{1. 緒言}

狭帯域性の不規則励振が Duffing 系などの剛性非線形系 に作用した場合，応答の標本関数において，振幅が時間的 に急激に変化し, 大振幅と小振幅との推移がランダムに発 生する，確率論的なジャンプ現象が生じることがある.

一自由度非線形系において, 複素ウェーブレット変換を 用いて励振と応答の位相差を抽出することによって，応答 の大振幅又は小振幅状態の判別が出来ることが示されてい る(1) が，多自由度系に対しては調べられていない。

本研究では, 多自由度非線形系の一つとして, 二自由度 Duffing 系を取り上げ, 複素ウェーブレット変換を用いて, 確率論的ジャンプ現象の解析を行った.

\section{2. 基礎方程式}

同一の Duffing 系を直列に接続した二自由度 Duffing 系 を考える.

$$
\left.\begin{array}{c}
\ddot{x}_{1}+2 \zeta \omega_{0}\left(2 \dot{x_{1}}-\dot{x_{2}}\right) \\
+\omega_{0}^{2}\left\{\left(2 x_{1}-x_{2}\right)+\epsilon x_{1}^{3}-\epsilon\left(x_{2}-x_{1}\right)^{3}\right\}=f(t) \\
\ddot{x}_{2}+2 \zeta \omega_{0}\left(\dot{x}_{2}-\dot{x}_{1}\right) \\
\quad+\omega_{0}^{2}\left\{\left(x_{2}-x_{1}\right)+\epsilon\left(x_{2}-x_{1}\right)^{3}\right\}=0
\end{array}\right\}
$$

不規則励振力 $f(t)$ は, 平均值 0 , 自己相関関数 $R(\nu)$ のガ ウス性定常非白色雑音とし, $R(\nu)$ は以下の指数减衰調和関 数を考える.

$$
R(\nu)=R_{0} e^{-\alpha|\nu|} \cos \rho \nu
$$

励振の帯域幅を表す無次元パラメータ $A$ を線形一自由度系 $(\epsilon=0)$ の周波数応答関数のピークの鋭さを表す $\zeta \omega_{0}$ に対 応する比とし, 励振の卓越角振動数を表す無次元パラメー タ $B$ を減衰固有角振動数 $\omega_{0} \sqrt{1-\zeta^{2}}$ に対応する比として, 次式のように導入する.

$$
A=\frac{\alpha}{\zeta \omega_{0}}, \quad B=\frac{\rho}{\omega_{0} \sqrt{1-\zeta^{2}}}
$$

本研究の計算において，系のパラメータおよび励振の帯 域幅を表す $A$ と励振の強さを表す $R_{0}$ を以下の值に固定し た場合を考える.

$$
\zeta=0.05, \omega_{0}=1.0, \epsilon=0.1, A=0.01, R_{0}=1.0
$$

$\epsilon>0$ の硬性バネを考えるので，大振幅と同位相，小振幅 と逆位相が対応する. また, 励振の卓越角振動数を表す $B$ は一次モードのピーク付近である $B=0.8$, 各応答の位 相が反転する $B=1.05$, 二次モードのピーク付近である $B=2.0$ とする.

\section{3. ウェーブレット変換による位相差}

関数 $x(t)$ に対して, マザーウェーブレット $\psi(t)$ による 連続ウェーブレット変換は次式で定義される ${ }^{(2)}$.

$$
\tilde{c}_{x}(a, b)=\int_{-\infty}^{\infty} \frac{1}{\sqrt{a}} \psi^{*}\left(\frac{t-b}{a}\right) x(t) d t
$$

ここで，*は複素共役である，本研究では $\psi(t)$ を次式のモ ルレーウェーブレットとする.

$$
\psi(t)=\frac{1}{\pi^{\frac{1}{4}}} e^{i 2 \pi f_{0} t} e^{-\frac{t^{2}}{2}}
$$

中心振動数 $f_{0}$ をよく用いられる $\frac{5}{2 \pi}$ とすると, モルレー ウェーブレットの卓越角振動数は $\Omega=5$ となる.

一般的にウェーブレット変換結果を示すとき，縦軸にス ケールパラメータ $a$, 横軸に時間 $t$ が用いられることが多 いが，本研究ではマザーウェーブレットの卓越角振動数を 用いた次式による変数変換により，縦軸を周期 $T$ で示して いる.

$$
a=\frac{\Omega T}{2 \pi}
$$

これにより，位相と周期の関係が明らかとなる，本研究に おけるウェーブレット変換結果の着目すべき周期 $T$ は, 式 (3) と式 (6) より，表 1 の関係となる.

また, 励振のウェーブレット変換 $c_{f}^{*}(T, t)$ と, 応答のウ エーブレット変換 $c_{x}(T, t)$ の偏角を取ることにより, 励振 と応答の位相差を得ることができる ${ }^{(1)}$.

$$
\phi_{f x}(T, t)=\arg \left\{c_{f}^{*}(T, t) \quad c_{x}(T, t)\right\}
$$

Table 1 Relation between $B$ and $T$

\begin{tabular}{|l||l|l|l|}
\hline$B$ & 0.8 & 1.0 & 2.0 \\
\hline$T$ & 7.9 & 6.3 & 3.1 \\
\hline
\end{tabular}

\section{4. 狭帯域不規則励振によるジャンプ現象}

図 1 に $B=0.8$, 図 2 に $B=1.05$, 図 3 に $B=2.0$ の場 合のそれぞれの応答の標本関数および, ウェーブレット変 換による励振と応答の位相差を示す. 各図において, (a) (b) は忘答 $x_{1}, x_{2}$ の標本関数であり, $(\mathrm{c})(\mathrm{d})$ はウェーブレッ 卜変換による励振と応答 $x_{1}, x_{2}$ の位相差である.

まず, $B=0.8$ の場合, 図 1(a)(b) の応答の標本関数よ り， $x_{1}$ および $x_{2}$ で確率論的ジャンプ現象が発生している ことがわかる. (c)(d) のウェーブレット変換による位相差 


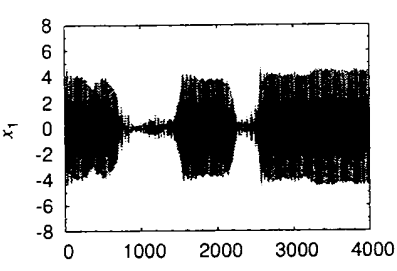

(a)Response $x_{1}$

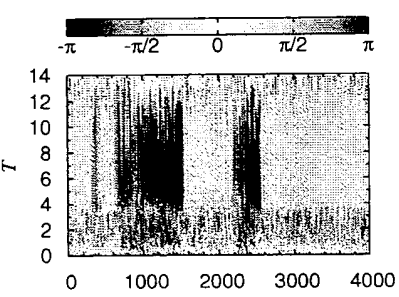

(c) Phase angle between $f$ and $x_{2}$

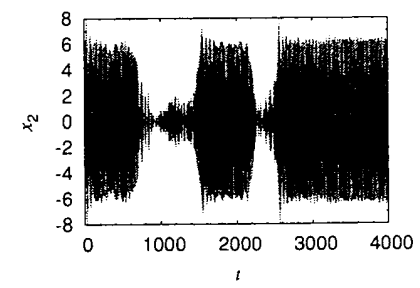

(b)Response $x_{2}$

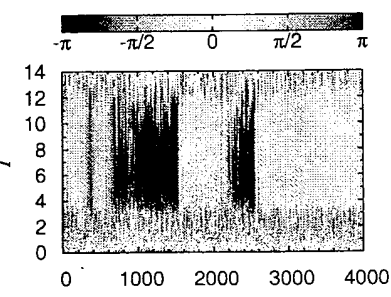

(d)Phase angle between $f$ and $x_{2}$
Fig. 1 Sample functions of response $(B=0.8)$

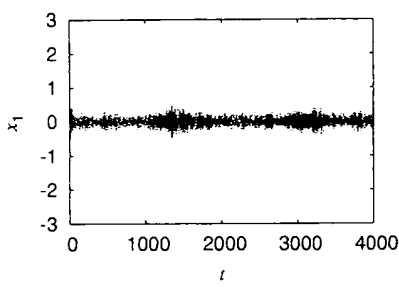

(a)Response $x_{1}$

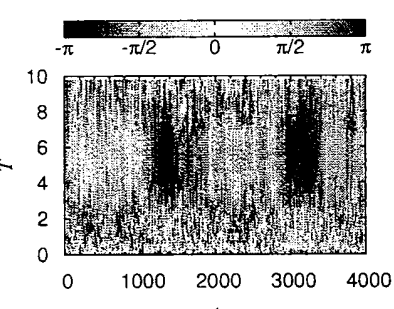

(c) Phase angle between $f$ and $x_{2}$

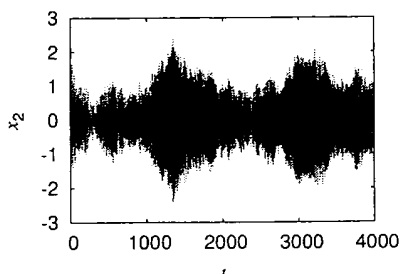

(b)Response $x_{2}$
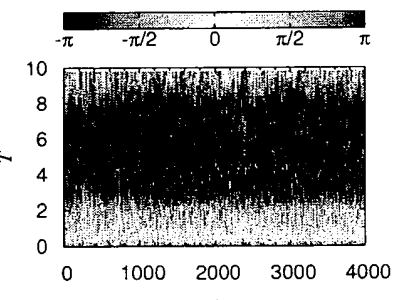

(d)Phase angle between $f$ and $x_{2}$
Fig. 2 Sample functions of response $(B=1.05)$

においても，同位相の 0 付近から逆位相の $-\pi$ または $\pi$ 付 近に変化していることより, 確率論的ジャンプ現象が発生 していることがわかる，また，(c)(d) より応答 $x_{1}$ と $x_{2}$ が 同位相であるので，一次モードであることがわかる.

次に, $B=1.05$ の場合, 図 $2(\mathrm{a})(\mathrm{b})$ の応答の標本関数 では，図 1 の $B=0.8$ の場合に比べて比較的小振幅である ことがわかる.また，(a)(b) からはジャンプ現象が発生し ていることは確認できない.しかし，(d) のウェーブレッ 卜変換結果では， $-\pi$ と $\pi$ が入り乱れていることがわかる. これは， B=1.05 付近で一次モードと二次モードの中間と なるため、どちらのモードでもない中間的な位相差が出て いると考えられる.

最後に, $B=2.0$ の場合, 図 $3(\mathrm{a})(\mathrm{b})$ の応答の標本関数 より， $x_{1}$ および $x_{2}$ で確率論的ジャンプ現象が発生してい

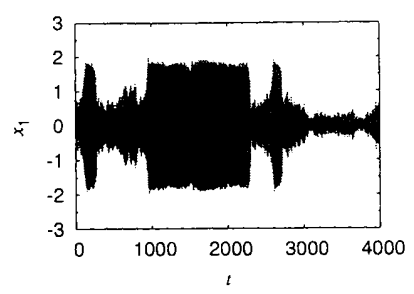

(a)Response $x_{1}$

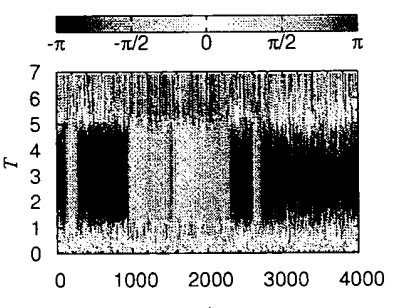

(c) Phase angle between $f$ and $x_{2}$

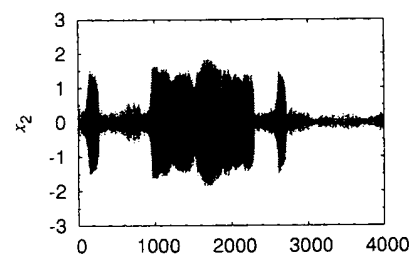

(b)Response $x_{2}$

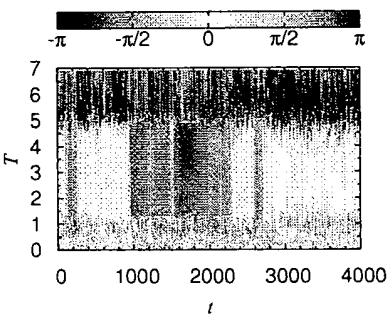

(d)Phase angle between $f$ and $x_{2}$
Fig. 3 Sample functions of response $(B=2.0)$

ることがわかる. (c) のウェーブレット変換による位相差に おいても，同位相の 0 付近から逆位相の $-\pi$ または $\pi$ 付近 に変化していることおよび, (d) のウェーブレット変換に よる位相差では，逆位相の一ー または $\pi$ 付近から同位相の 0 付近に変化していることから, 確率論的ジャンプ現象が 発生していることがわかる.また, (c)(d) より忍答 $x_{1}$ と $x_{2}$ が逆位相であるので，二次モードであることがわかる.

\section{5. 結論}

同一の Duffing 系を直列に接続した二自由度 Duffing 系 に対して, ウェーブレット変換による励振と応答の位相差 を用いて確率論的ジャンプ現象の解析を行った. 本研究で 得られた知見を以下に示す。

- 励振力が系の連成固有角振動数に近い卓越角振動数を 持つ場合，対応するモードにおいて確率論的ジャンプ 現象が発生する。

- 励振力の卓越角振動数が系の 2 つの連成固有角振動数 の中間となる場合, 各亡ードに対応しない位相差を取 万.

\section{文献}

（1）田村晋司・舟越良文，ウェーブレット変換を用いた Duffing 系の不規則応答におけるジャンプ現象の解析 (第 2 報, 複素ウェーブレット変換による解析), 機講 論, 10-8, (2010), 64 .

(2) P.S.Addison（新 誠一，中野和司 監訳）, 図説ウ ェーブレット変換ハンドブック, (2005), 1-70, 朝倉 書店.

（3）田村晋司・鈴木康弘・木村康治，狭带域不規則励振を 受ける Duffing 系の確率論的ジャンプ現象の各種統計 量, 機論 C, 75-754, (2009), 1560-1567. 